\title{
Pengaruh Kompetisi, Pertumbuhan Laba dan Kinerja Lingkungan terhadap Pengungkapan Informasi Emisi Karbon pada Perusahaan
}

\author{
Hilmi \\ Universitas Malikussaleh \\ Lhokseumawe, Indonesia \\ hilmi@unimal.ac.id
}

\author{
Lilis Puspitawati \\ Universitas Komputer Indonesia Bandung, \\ Indonesia \\ lilis.puspitawati@email.unikom.ac.id
}

\section{Ranti Utari \\ Universitas Malikussaleh \\ Lhokseumawe, Indonesia \\ $\underline{\text { Rantiutari2@gmail.com }}$}

Corresponding Author: Lilis Puspitawati

Submitted: 5 Mei 2020

Accepted: 2 Juli 2020

Published: 1 Agustus 2020

ABSTRACT

Disclosure of carbon emissions (Carbon Emission Disclosure) is a voluntary disclosure of carbon emissions resulting from the company's production process. This research itself aims to obtain empirical evidence about competition, profit growth and environmental performance on the disclosure of carbon emissions of manufacturing companies listed on the Indonesia Stock Exchange in the 2015-2018 period. The method applied to measure the extent of disclosure of carbon emissions adopted from the check list developed based on the request sheet obtained from the Carbon Disclosure Project (CDP). The results of this study indicate that competition, profit growth and environmental performance have no effect on Carbon Emission Disclosure.

Keywords: Carbon Emission Disclosure, Competition, Profit Growth, and Environmental Performance

\section{PENDAHULUAN}

Peran perusahaan sangat penting dalam mengembangkan perekonomian suatu Negara terutama bagi masyarakat di Negara tersebut. Perusahaan dapat memberikan dampak positif dan juga dampak negatif, salah satu dampak yang dihasilkan perusahaan ialah perubahan iklim. Belakangan ini isu-isu mengenai perubahan iklim merupakan salah satu fenomena 
lingkungan yang terbesar dalam beberapa tahun terakhir. Pada tahun 2017 suhu global rata-rata berkisar $1,1^{\circ} \mathrm{C}$ diatas tingkat praindustri. Sayangnya pada saat ini sudah berada di jalur menuju batas $1,5^{\circ} \mathrm{C}$ dan tren pemanasan berkelanjutan tidak menunjukkan adanya tanda-tanda akan menurun. Pada dua dekade terakhir termasuk kedalam 18 tahun terpanas sejak dimulainya pencatatan pada 1850 hingga saat ini (Ahmad, N. and D. M. Hossain. 2015)

Aktivitas manusia yang paling besar menyumbang emisi gas rumah kaca adalah aktivitas industri. Pusat analisis informasi Karbon Dioksida DepartemenEnergi AS (CDIAC) pada tahun 2018 menyatakan bahwa Emisi karbon dioksida mengalami kenaikan pada 150 tahun terakhir saat dunia industri mulai tumbuh. Karbon dioksida yang disebabkan oleh manusia telah meningkat lebih dari 400 miliar ton ke atmosfer sejak 1751 menurut data yang dikeluarkan Carbon Dioxide Information Analysis Center (CDIAC) atau Pusat Analisis Informasi Karbon Dioksida Departemen Energi AS. Tidak dapat dipungkiri bahwa berbagai sektor bisnis atau industri sudah berpotensi hebat dalam meningkatkan pertumbuhan ekonomi dan menjadi prioritas pembangunan di setiap provinsi di Indonesia, tetapi kegiatan ini memiliki potensi untuk melepaskan emisi GRK dan berkontribusi bagi global pemanasan dan perubahan iklim (Utama. M, 2014). . Oleh karena itu, perusahaan mempunyai tanggung jawab sosial dalam mendukung upaya pengurangan emisi dan pencegahan pemanasan global lebih lanjut. Bentuk ini dari tanggung jawab sosial yang dapat diketahui dari Pengungkapan Emisi Karbon.

Secara konseptual, pengungkapan merupakan bagian integral dari pelaporan keuangan. Secara teknis, pengungkapan merupakan langkah akhir dalam proses akuntansi yaitu penyajian informasi dalam bentuk seperangkat penuh Laporan keuangan. Pengungkapan emisi karbon dalam pelaporan keuangan merupakan hal yang penting dilakukan oleh perusahaan karena dengan adanya pengungkapan emisi karbon dapat menjadi suatu corporate action yang baik dalam rangka menjaga keseimbangan sistem kehidupan yang ada di Bumi. Perusahaan yang mengungkapkan informasi emisi karbon cenderung akan menerapkan prinsip sustainability ke dalam strategi dan operasi perusahaan sehingga investor diharapkan dapat mempertimbangkan informasi karbon sebagai bahan pengambilan keputusan investasi (Kelvin, Chen. 2019).

Beberapa acuan yang digunakan dalam penghitungan emisi karbon oleh perusahaan Indonesia mengacu pada ketentuan protokol CO2 yang diadopsi dari standar yang dikeluarkan oleh World Bussiness Council for Sustainable Development/World Resources Institute (WBCSD-WRI) dan United Nation Enviroment Progamme (UNEP) yang diberlakukan sejak tahun 2016. . Penelitian yang dilakukan berkaitan dengan perubahan iklim dan emisi karbon dan telah dikembangkan oleh Choi, et.al (2013), .berdasarkan lembar permintaan informasi yang diberikan oleh CDP (Carbon Disclosure Project).

\section{LANDASAN TEORI}

\subsection{Teori Legitimasi}

Teori legitimasi menyatakan bahwasannya jika dilihat dari sudut pandang sistem organisasi, pengungkapan memiliki peran penting dalam menghubungkan antara organisasi perusahaan, perusahaan serta perkumpulan sebuah kelompok (Irwhantoko dan Basuki, 2016). Salah satu teori yang mendasari adanya insentif entitas yang dengan sukarela melakukan pengungkapan laporan pertanggung jawaban sosial serta 
lingkungan adalah teori legistimasi (Luo. et.al, 2013).

\subsection{Teori Stakeholder}

Teori stakeholder menyatakan bahwasannya perusahaan bukanlah sebuah entitas yang hanya beroperasi untuk memikirkan kepentingan sendiri tetapi harus memberikan manfaat bagi stakeholdernya. Keberadaaan suatu perusahaan sangat dipengaruhi oleh dukungan yang diberikan oleh stakeholder kepada perusahaan tersebut (Ghozali dan Chariri, 2007).

\subsection{Emisi Karbon}

Emisi karbon ialah proses pelepasan gas-gas yang mengandung karbon ke lapisan atsmosfer. Pelepasan tersebut terjadi karena adanya suatu proses pembakaran terhadap karbon baik dalam bentuk senyawa maupun tunggal. Berdasarkan sumbernya emisi karbon ataupun gas rumah kaca (greenhouse gas) dibedakan menjadi dua yakni gas rumah kaca industri dan gas rumah kaca alami.

Merujuk pada United States Enviromental Protection Agency (2014), bahwa aktivitas manusia membuat kadar karbondioksida menjadi lebih padat sehingga alam tidak dapat menyerap seluruh karbondioksida yang tersedia dan terjadi kelebihan karbon. Sesudah era revolusi industri, penyumbang terbesar karbondioksida di atsmofer adalah manusia.

\subsection{Pengungkapan Emisi Karbon}

Cara yang dapat ditempuh perusahaan untuk melegitimasi aktivitasnya adalah dengan cara melakukan pengungkapan ke public (Suhardi, 2015). Dalam menghadapi perubahan iklim perusahaan diharapkan melakukan pengungkapan kegiatan perusahaan yang berperan dalam perubahan iklim salah satunya carbon emission disclosure. Lahirnya emisi karbon membuat perusahaan lebih dituntut terbuka dalam memberikan informasi perusahaan tersebut. Pengungkapan informasi dalam laporan tahunan dikelompokkan menjadi dua yakni mandatory disclosure dan voluntary disclosure. Pengungkapan emisi gas rumah kaca yang dilakukan di Indonesia masih bersifat sukarela (voluntary disclosure), sehingga tidak semua perusahaan mengungkapkan informasi tersebut pada laporannya (Supriadi dkk, 2016).

Dalam penelitian ini digunakan indeks pengungkapan emisi karbon yang telah dikembangkan oleh Choi et al, (2013) dan (Suhardi, 2015), dimana bentuk dari pengungkapan ini dibuat berdasarkan faktorfaktor yang telah teridentifikasi pada information request sheet yang telah dikembangkan oleh Carbon Disclosure Project (CDP). CDP (Carbon Disclosure Project) membagi pengungkapan dalam 5 kategori sebagai berikut: risiko dan peluang perubahan iklim (CC/Climate Change), emisi gas rumah kaca (GHG/Greenhouse Gas), konsumsi energi (EC/Energy Consumption), pengurangan gas rumah kaca dan biaya (RC/Reduction and Cost) serta akuntabilitas emisi karbon (AEC/Accountability of Emission Carbon)

\subsection{Kompetisi (Competition)}

Dalam Kamus Besar Bahasa Indonesia kompetisi dapat diartikan sebagai persaingan atau bersaing. Perusahaan yang lebih kompetitif cenderung melakukan pengungkapan informasi lebih luas guna untuk mengurangi asimetri informasi antara manajemen dengan shareholder. Sementara perusahaan yang kurang kompetitif cenderung akan menghindari pengungkapan yang dapat diketahui lawan (Birt et al, 2006).

\subsection{Pertumbuhan Laba}

$\begin{array}{crr}\text { Pertumbuhan } & \text { (growth) } & \text { adalah } \\ \text { seberapa jauh perusahaan mampu }\end{array}$ menempatkan diri didalam sistem ekonomi 
keseluruhan atau untuk sistem industri yang sama (Machfoedz, Mas'ud. 1996). Pertumbuhan perusahaan mengisyaratkan kemampuan perusahaan dalam mempertahankan kelangsungan perusahaan (Safrida, Eli. 2014). Untuk meningkatkan size perusahaan diperlukan sebuah pertumbuhan perusahaan. Pertumbuhan laba menunjukkan sampai sejauh mana perusahaan mampu meningkatkan kemampuannya dalam memperoleh keuntungan bersih dibandingkan dengan total keuangan secara keseluruhan (Kasmir, 2012).

\subsection{Kinerja Lingkungan}

Kinerja lingkungan merupakan usaha perusahaan dalam menciptakan lingkungan yang lebih baik. Pengungkapan lingkungan di Indonesia merupakan pengungkapan sukarela. Sudah waktunya perusahaan merasa khawatir mengenai aspek lingkungan mengingat dampak yang telah diciptakan oleh operasi perusahaan terhadap lingkungan (Suratno dkk, 2006).

Selanjutnya kerangka kerja dalam penelitian ini dinyatakan dalam gambar 2.1 sebagai berikut:

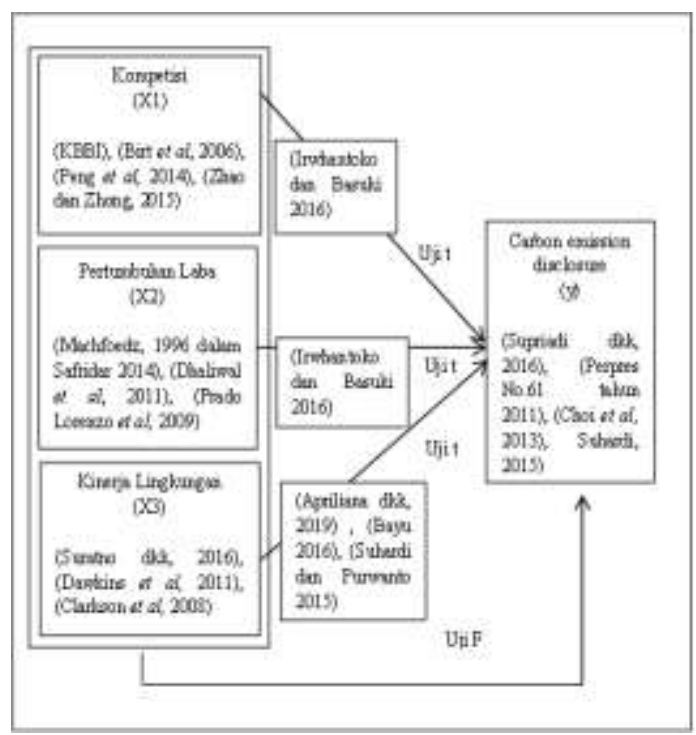

Gambar 2.1 Kerangka Konseptual

\subsection{Hipotesis Penelitian}

Berdasarkan kerangka konseptual penelitian diatas, dan didukung oleh teori yang ada maka penulis membuat hipotesis sebagai berikut:

H1 Kompetisi berpengaruh terhadap

$=$ pengungkapan emisi karbon

H2 Pertumbuhan Laba berpengaruh

$=$ terhadap pengungkapan emisi karbon

H3 Kinerja Lingkungan berpengaruh

$=$ terhadap pengungkapan emisi karbon

H4 Kompetisi, pertumbuhan laba dan

$=\quad$ kinerja lingkungan berpengaruh terhadap pengungkapan emisi karbon

\section{III. METODE PENELITIAN \\ 3.1. Lokasi dan Objek Penelitian}

Lokasi penelitian adalah tempat dimana proses studi yang digunakan untuk memperoleh pemecahan masalah penelitian berlangsung (Sukardi. 2008). Adapun lokasi di dalam penelitian ini yaitu pada perusahaan manufaktur yang terdaftar di Bursa Efek Indonesia.

Objek penelitian adalah sasaran ilmiah untuk mendapatkan data dengan tujuan dan kegunaan tertentu tentang sesuatu hal yang objektif, valid dan reliable tentang suatu hal (Sugiyono, 2015). Adapun Objek pengamatan terbatas pada laporan tahunan (annual report) periode 2015-2018 yang diunduh melalui website www.idx.co.id dan dari masing-masing situs resmi perusahaan.

\subsection{Populasi dan Sampel}

Populasi adalah sebuah wilayah generalisasi yang terdiri atas subjek ataupun objek yang memiliki kualitas dan karakteristik tertentu yang telah ditetapkan oleh peneliti untuk dipelajari lalu ditarik kesimpulannya (Sugiyono, 2012). Adapun populasi di dalam penelitian ini adalah 
perusahaan manufaktur yang terdaftar di Bursa Efek Indonesia (BEI) selama periode 2015-2018. Sampel adalah sebagian dari elemen-elemen populasi. Selanjutnya Arikunto, S (2006) menjelaskan bahwa sampel adalah wakil populasi atau sebagai yang diteliti. Pengambilan sampel di dalam penelitian ini menggunakan teknik Purposive Sampling.

Adapun kriteria-kriteria yang dijadikan sebagai sampel penelitian yaitu:

1. Perusahaan manufaktur yang terdaftar di BEI selama periode tahun 2015-2018.

2. Perusahaan manufaktur yang menyediakan data terkait variabel penelitian dan menyediakan annual report 2015-2018.

3. Perusahaan manufaktur yang melaporkan laporan keuangannya dalam Rupiah.

\subsection{Operasional Variabel}

Operasionalisasi variabel selanjutnya disajikan dalam tabel 2.1 sebagai berikut:

Tabel 2.1 Operasional Variabel

\begin{tabular}{|c|c|c|}
\hline Variabel & Indikator & Skala \\
\hline $\begin{array}{l}\text { Pengungkapan } \\
\text { informasi } \\
\text { emisi karbon / } \\
\text { carbon } \\
\text { emission } \\
\text { disclosure }\end{array}$ & $\begin{array}{l}\mathrm{CED}=(\Sigma \mathrm{di} / \mathrm{M}) \\
\mathrm{Ket}: \\
\sum \mathrm{di}=\text { total keseluruhan skor } 1 \text { yang dapat diungkapkan } \\
\mathrm{M}=\text { total item maksimal yang dapat diungkapkan }(18 \text { item })\end{array}$ & Rasio \\
\hline $\begin{array}{l}\text { Kompetisi } \\
\text { (competition) }\end{array}$ & $\begin{array}{l}\sum_{i=1}^{n}\left[S_{j t} / S_{t}\right]^{2} \\
\text { Ket: } \\
\text { Sjt=Nilai penjualan perusahaan } \mathrm{j} \text { tahun } \mathrm{t} \\
\mathrm{St}=\text { Total penjualan Semua perusahaan manufaktur pada tahun } \\
\mathrm{t} \\
\mathrm{Sjt} / \mathrm{St}=\text { Pangsa pasar perusahaan } \mathrm{j} \text { tahun } \mathrm{t} \\
\mathrm{n}=\mathrm{Jumlah} \text { perusahaan di dalam industri manufaktur }\end{array}$ & Rasio \\
\hline $\begin{array}{l}\text { Pertumbuhan } \\
\text { laba (growth) }\end{array}$ & $\begin{array}{l}\Delta Y_{i t}=\frac{Y_{i t}-Y_{i t-1}}{Y_{i t-1}} \\
\text { Ket: } \\
\Delta \mathrm{Y}_{\text {it }}=\text { Pertumbuhan laba periode } \mathrm{t} \\
\mathrm{Y}_{\mathrm{it}}=\text { Laba sebelum pajak perusahaan i pada periode } \mathrm{t}\end{array}$ & Rasio \\
\hline
\end{tabular}

4. Perusahaan manufaktur yang melakukan pengungkapan emisi karbon (mencakup minimal satu kebijakan yang terkait dengan emisi karbon/gas rumah kaca atau mengungkapkan minimal satu item pengungkapan emisi karbon).

\subsection{Teknik Pengumpulan Data}

Teknik pengumpulan data merupakan sebuah langkah yang paling tetap dalam melakukan penelitian, karena tujuan utama dari penelitian adalah untuk mendapatkan data (Ghozali, Imam. 2013). Sesuai dengan jenis data yang digunakan pada penelitian ini yaitu jenis data sekunder, maka teknik pengumpulan data yang dilakukan pada penelitian ini adalah teknik dokumentasi dan teknik studi pustaka.

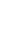




\begin{tabular}{|l|l|l|}
\hline & $Y_{\text {it-1 }}=$ Laba sebelum pajak perusahaan i pada periode t-1 & \\
\hline Kinerja & Pengukuran kinerja lingkungan mengacu pada berdasarkan & Interval \\
& peringkat warna PROPER yang didapat perusahaan & \\
& 0= tidak menjadi peserta & \\
1= Sangat buruk/ hitam & \\
2= buruk/ warna merah & \\
& 3= baik / warna biru & \\
& 4= sangat baik/ hijau & \\
& 5= sangat baik sekali/ warna emas & \\
\hline
\end{tabular}

\subsection{Analisis Data Penelitian: Uji Regresi Linear Berganda}

Adapun formulasi persamaan regresi linear berganda sebagai berikut :

$$
Y=\alpha+b_{1} X_{1}+b_{2} X_{2}+b_{3} X_{3}+e
$$

Keterangan:

$$
\begin{array}{lll}
\mathrm{Y}= & \text { Pengungkapan Emisi Karbon } \\
\alpha & = & \text { Harga Konstanta } \\
b_{1}, b_{2}, b_{3}= & \text { Koefisien Regresi } \\
X_{1}= & \text { Variabel Independen Pertama } \\
& \text { (Kompetisi) } \\
X_{2}= & \text { Variabel Independen Kedua } \\
& \text { (Pertumbuhan Laba) } \\
X_{3}= & \text { Variabel Independen Ketiga } \\
& \text { (Kinerja Lingkungan) } \\
\mathrm{e} & = & \text { Error atau Pengaruh Luar }
\end{array}
$$

\begin{tabular}{|l|l|r|}
\hline Parameters & Std. & .08334755 \\
a,b & Deviation & \\
\hline Most & Absolute & .139 \\
\cline { 2 - 3 } Extreme & Positive & .139 \\
\cline { 2 - 3 } Differences & Negative & -.072 \\
\hline Kolmogorov-Smirnov & 1.523 \\
$Z$ & \\
\hline \multicolumn{2}{|l|}{ Asymp.sig. (2-tailed) } & .019 \\
\hline
\end{tabular}

sumber: data olahan SPSS 17, 2019.

Berdasarkan hasil output Kolmogorov Smirnov menunjukkan nilai signifikan diatas 0,05 maka dapat dikatakan data terdistribusi normal.

\subsubsection{Uji Multikolinearitas}

Uji Multikolinearitas digunakan untuk menguji apakah variabel-variabel independen yang diteliti memiliki masalah keterkaitan satu dengan yang lainnya. Hasil pengujian Multikolinearitas berdasarkan software SPSS dapat dilihat dalam tabel 2.3 sebagai berikut:

4.1. Hasil Penelitian

\subsubsection{Uji Normalitas}

Uji Normalitas digunakan untuk menentukan data yang telah dikumpulkan telah berdistribusi normal Hasil uji normalitas dalam penelitian ini disajikan dalam tabel 2.2 sebagai berikut:

Tabel 2.2 . Uji Normalitas one-sample Kolmogorov-smirnov Test

\begin{tabular}{|l|l|r|}
\hline \multicolumn{2}{|l|}{} & $\begin{array}{c}\text { Unstandardized } \\
\text { Residual }\end{array}$ \\
\hline N & & 120 \\
\hline Normal & Mean & .0000000 \\
\hline
\end{tabular}


Tabel 2.3.Multikolinearitas

\begin{tabular}{|c|c|c|c|c|c|c|c|}
\hline \multirow[b]{3}{*}{ Model } & \multicolumn{7}{|c|}{ Coefficients $^{\mathrm{a}}$} \\
\hline & \multicolumn{2}{|c|}{$\begin{array}{l}\text { Unstand } \\
\text { ardized } \\
\text { Coeffici } \\
\text { ents }\end{array}$} & \multirow{2}{*}{\begin{tabular}{|c} 
Std \\
Coe \\
ff \\
\\
Bet \\
a
\end{tabular}} & \multirow[b]{2}{*}{$\mathrm{t}$} & \multirow[b]{2}{*}{ Sig. } & \multicolumn{2}{|c|}{$\begin{array}{l}\text { Collinea } \\
\text { rity } \\
\text { Statistics }\end{array}$} \\
\hline & B & $\begin{array}{l}\text { Std. } \\
\text { Err } \\
\text { or }\end{array}$ & & & & $\begin{array}{l}\text { Tol } \\
\text { era } \\
\text { nce }\end{array}$ & VIF \\
\hline $1 \mid$\begin{tabular}{l|l} 
(Const \\
ant)
\end{tabular} & $\begin{array}{r}.02 \\
8\end{array}$ & $\begin{array}{r}.05 \\
8\end{array}$ & & $\begin{array}{r}.48 \\
2\end{array}$ & $\begin{array}{r}.63 \\
1\end{array}$ & & \\
\hline $\begin{array}{l}\text { Komp } \\
\text { etisi }\end{array}$ & $\begin{array}{r}.40 \\
6\end{array}$ & $\begin{array}{r}.31 \\
0\end{array}$ & $\begin{array}{r}.11 \\
8\end{array}$ & $\begin{array}{r}1.3 \\
09\end{array}$ & $\begin{array}{r}19 \\
3\end{array}$ & & $\begin{array}{r}1.0 \\
03\end{array}$ \\
\hline $\begin{array}{l}\text { Pertu } \\
\text { mbuha } \\
\text { n Laba }\end{array}$ & $\begin{array}{r}.01 \\
4\end{array}$ & $\begin{array}{r}.01 \\
2\end{array}$ & $\begin{array}{r}- \\
.10 \\
3\end{array}$ & $\begin{array}{r}1.1 \\
27\end{array}$ & $\begin{array}{r}.26 \\
2\end{array}$ & $\begin{array}{r}.97 \\
1\end{array}$ & $\begin{array}{l}1.0 \\
30\end{array}$ \\
\hline $\begin{array}{l}\text { Kinerj } \\
\text { a } \\
\text { Lingk } \\
\text { ungan }\end{array}$ & $\begin{array}{r}.03 \\
7\end{array}$ & $\begin{array}{r}.01 \\
8\end{array}$ & $\begin{array}{r}.19 \\
2\end{array}$ & $\begin{array}{r}2.0 \\
91\end{array}$ & $\begin{array}{r}.03 \\
9\end{array}$ & $\begin{array}{r}.97 \\
3\end{array}$ & $\begin{array}{l}1.0 \\
27\end{array}$ \\
\hline $\begin{array}{l}\text { Deper } \\
\text { Disclosu }\end{array}$ & & & & & & & \\
\hline
\end{tabular}

Sumber: hasil Pengolahan SPSS 17,2019

Berdasarkan tabel 2.3, maka dapat diketahui nilai toleransi dan VIF untuk masing masing variabel penelitian adalah Nilai VIF untuk variabel kompetisi, pertumbuhan laba dan kinerja lingkungan lebih kecil dari 10 dan nilai toleransi lebih besar dari 0,10. Sehingga variabel kompetisi, pertumbuhan laba dan kinerja lingkungan dinyatakan tidak terjadi multikolinieritas.

\subsubsection{Uji Autokorelasi}

uji Auto korelasi bertujuan untuk Uji Autokorelasi adalah sebuah analisis statistik yang dilakukan untuk melihat apakah terdapat korelasi variabel yang ada di dalam model dengan perubahan waktu. Oleh karena itu, apabila asumsi autokorelasi terjadi pada sebuah model prediksi, maka nilai disturbance tidak lagi berpasangan secara bebas, melainkan berpasangan secara autokorelas. Hasil pengujian autokorelasi berdasarkan software SPSS dapat dilihat dalam tabel 2.4 sebagai berikut:

Tabel 2.4 Uji Autokorelasi

\begin{tabular}{|c|c|c|c|c|c|}
\hline \multicolumn{6}{|c|}{ Model Summary ${ }^{b}$} \\
\hline Model & $\mathrm{R}$ & $\begin{array}{c}\mathrm{R} \\
\text { Square }\end{array}$ & $\begin{array}{l}\text { Adjusted } \\
\text { R Square }\end{array}$ & $\begin{array}{l}\text { Std. Error } \\
\text { of the } \\
\text { Estimate }\end{array}$ & $\begin{array}{l}\text { Durbin- } \\
\text { Watson }\end{array}$ \\
\hline 1 & $.231^{\mathrm{a}}$ & .053 & .029 & .0844184 & 1.176 \\
\hline \multicolumn{6}{|c|}{$\begin{array}{l}\text { a. Predictors: (Constant), Kinerja Lingkungan, } \\
\text { Kompetisi, Pertumbuhan Laba }\end{array}$} \\
\hline \multicolumn{6}{|c|}{$\begin{array}{l}\text { b. Dependent Variable: Carbon Emission } \\
\text { Disclosure }\end{array}$} \\
\hline
\end{tabular}

Sumber: hasil Pengolahan SPSS 17,2019

Berdasarkan hasil perhitungan Tabel 2.4 nilai DW sebesar 2,101 dengan jumlah $\mathrm{k}$ (variabel independen) sebanyak 3 dan jumlah sampel sebanyak 120. Dalam tabel Durbin Watson menunjukkan nilai $\mathrm{dL}$ (batas bawah) = 1,6513 ,nilai dU (batas atas) $=1,7536 \mathrm{dan}$ nilai $\mathrm{DW}=1,176$. Sehingga nilai $\mathrm{DW}$ lebih kecil dari dU dan kurang dari $(4-\mathrm{dU})=4$ $1,7536=2,2464$. Sehingga dapat disimpulkan bahwa telah terjadi autokorelasi pada model regresi. Karena regresi mengandung masalah autokorelasi positif maka diperlukan tindakan perbaikan. Untuk melakukan perbaikan maka digunakan Cochrane Orcutt. yang hasilnya disajikan dalam tabel 2.5 sebagai berikut: 
Tabel 2.5 Uji Cochrane Orcutt

\begin{tabular}{|l|r|r|r|r|r|}
\hline \multicolumn{7}{|c|}{ Model Summary } \\
\hline Model & $\mathrm{R}$ & $\begin{array}{c}\mathrm{R} \\
\text { Square }\end{array}$ & $\begin{array}{c}\text { Adjusted } \\
\mathrm{R} \\
\text { Square }\end{array}$ & $\begin{array}{c}\text { Std. } \\
\text { Error of } \\
\text { the } \\
\text { Estimate }\end{array}$ & $\begin{array}{l}\text { Durbin- } \\
\text { Watson }\end{array}$ \\
\hline 1 & $.147^{\mathrm{a}}$ & .022 & -.004 & .07694 & 2.057 \\
\hline $\begin{array}{l}\text { a. Predictors: (Constant), Lag_X3, Lag_X1, } \\
\text { Lag_X2 }\end{array}$ \\
\hline
\end{tabular}

sumber: hasil Pengolahan SPSS 17,2019

Pada Tabel 2.5 nilai durbin Watson dengan menggunakan metode Cochrane orcutt menunjukkan nilai $\mathrm{dL}$ (batas bawah) = 1,6513 dan nilai dU (batas atas) $=1,7536$ sehingga nilai $\mathrm{DW}=2,057$ lebih besar dari $\mathrm{dU}$ dan kurang dari $(4-d U)=4-1,7536=2,2464$. Sehingga dapat disimpulkan tidak terjadi autokorelasi pada model regresi.

\subsubsection{Uji Heteroskedastisitas}

Uji Heterokedastisitas merupakan salah satu uji asumsi klasik yang digunakan untuk menguji apakah dalam model regresi terjadi kesamaan varians (variasi) dari residual dari satu pengamatan ke pengamatan yang lainnya. Hasil Uji heterokedastisitas dalam penelitian ini selanjutnya disajikan dalam tabel 2.6 sebagai berikut:

Tabel 2.6. Uji Heterokesdastisitas

\begin{tabular}{|c|c|c|c|c|c|c|}
\hline \multicolumn{7}{|c|}{ Coefficients $^{\mathbf{a}}$} \\
\hline & \multirow[b]{2}{*}{ Model } & \multicolumn{2}{|c|}{$\begin{array}{c}\text { Unstandardized } \\
\text { Coefficient }\end{array}$} & \multirow{2}{*}{$\begin{array}{c}\text { Stand } \\
\text { dized } \\
\text { Coef } \\
\text { ficient } \\
\text { Beta }\end{array}$} & \multirow[b]{2}{*}{$\mathrm{T}$} & \multirow[b]{2}{*}{ Sig. } \\
\hline & & B & $\begin{array}{l}\text { Std. } \\
\text { Error }\end{array}$ & & & \\
\hline \multirow[t]{4}{*}{1} & (Constant) & -10.214 & 1.670 & & -6.114 & .000 \\
\hline & LNX1 & .077 & .127 & .079 & .612 & .543 \\
\hline & LNX2 & -.023 & .147 & -.020 & -.158 & .875 \\
\hline & LNX3 & 3.641 & 1.403 & .343 & 2.595 & .012 \\
\hline
\end{tabular}

a. Dependent Variable: LNei2

sumber: hasil pengolahan SPSS 17, 2019

Berdasarkan hasil uji heterokedestisitas pada tabel diatas tidak terdapat variabel independen (kompetisi, pertumbuhan laba dan kinerja lingkungan) yang memiliki nilai signifikansi hitung (Sig) diatas 0,05 dalam penelitian ini, maka dapat disimpulkan bahwa terjadi gejala heteroskedastisitas pada variabel bebas.

\subsubsection{Pengujian Regresi Linear Berganda} Hasil Uji Regresi Linear Berganda ditampilkan pada Tabel Berikut ini:

Tabel 2.7. Uji Regresi Linear berganda

\begin{tabular}{|c|c|c|c|c|c|c|}
\hline \multicolumn{7}{|c|}{ Coefficients $^{\mathrm{a}}$} \\
\hline \multirow{2}{*}{\multicolumn{2}{|c|}{ Model }} & \multicolumn{2}{|c|}{$\begin{array}{l}\text { Unstand. } \\
\text { Coef. }\end{array}$} & \multirow{3}{*}{$\begin{array}{l}\text { Stand. } \\
\text { Coef. } \\
\text { Beta }\end{array}$} & \multirow{3}{*}{\begin{tabular}{l|}
$\mathrm{t}$ \\
.482 \\
\end{tabular}} & \multirow{3}{*}{$\begin{array}{l}\text { Sig. } \\
.631\end{array}$} \\
\hline & & $\mathrm{B}$ & $\begin{array}{l}\text { Std. } \\
\text { Error }\end{array}$ & & & \\
\hline 1 & (Constant) & $\begin{array}{l}\mathbf{D} \\
.028\end{array}$ & \begin{tabular}{|r|}
.058 \\
\end{tabular} & & & \\
\hline & Kompetisi & .406 & .310 & .118 & 1.309 & .193 \\
\hline & $\begin{array}{l}\text { Pertumbuh } \\
\text { an Laba }\end{array}$ & -.014 & .012 & -.103 & -1.127 & .262 \\
\hline & $\begin{array}{l}\text { Kinerja } \\
\text { Lingkungn }\end{array}$ & .037 & .018 & .192 & 2.091 & .039 \\
\hline
\end{tabular}

sumber: hasil Pengolahan SPSS 17,2019 
Berdasarkan hasil perhitungan dari uji regresi linear berganda diperoleh dari nilai konstanta (a) dari model regresi $=0.028$. Untuk koefisien regresi $\left(b_{1}\right)$ sebesar 0.406 , koefisien regresi $\left(b_{2}\right)$ sebesar -0.014. Dan koefisien regresi $\left(b_{3}\right)$ sebesar 0.037 .

Berdasarkan nilai konstanta dan koefisien regresi tersebut, maka hubungan antara variabel-variabel independen dengan variabel dependen dalam model regresi dirumuskan sebagai berikut:

\section{$Y=0.028+0.406-0.014+0.037+e$}

1. Konstanta $(a)=0,028$ artinya jika variabel kompetisi, pertumbuhan laba dan kinerja lingkungan dianggap konstan maka nilai pengungkapan emisi karbon sebesar 0,028 .

2. Untuk nilai koefisien regresi (X1) untuk variabel kompetisi bernilai 0,406 . Hal ini menunjukkan bahwa adanya hubungan positif terhadap pengungkapan emisi karbon setiap peningkatan kompetisi adalah sebesar $1 \%$ maka akan meningkatkan pengungkapan emisi karbon yang diterima adalah sebesar 0,406 .

3. Untuk nilai koefisien regresi (X2) untuk variabel pertumbuhan laba bernilai 0.014. Hal ini menunjukkan bahwa nilai pertumbuhan laba memiliki hubungan negatif terhadap pengungkapan emisi karbon. Artinya setiap kejadian kenaikan sebesar $1 \%$ dari nilai pertumbuhan laba maka akan menurunkan tingkat pengungkapan emisi karbon yang diterima adalah sebesar -0.014

4. Untuk nilai koefisien regresi (X3) untuk variabel kinerja lingkungan bernilai 0.037. Hal ini menunjukkan bahwa adanya hubungan positif terhadap pengungkapan emisi karbon setiap peningkatan kinerja lingkungan adalah sebesar 1\% maka akan meningkatkan pengungkapan emisi karbon yang diterima adalah sebesar 0.037 .

\subsection{Pembahasan Penelitian}

\subsubsection{Pengaruh Kompetisi terhadap Pengungkapan Emisi Karbon}

Hasil penelitian ini menujukkan bahwa $\mathrm{H}_{1}$ di tolak yang berarti kompetisi tidak memiliki pengaruh terhadap pengungkapan emisi karbon. Hal ini dapat dilihat dari nilai t signifikan 0.193>0.05. Dengan demikian penelitian ini menolak $\mathrm{H}_{1}$ yang menyatakan bahwa kompetisi tidak berpengaruh terhadap pengungkapan emisi karbon.

Hasil penelitian ini mendukung penelitian Irwhantoko dan basuki (2016) bahwa kompetisi tidak berpengaruh terhadap pengungkapan emisi karbon. Hal ini memberi kesan bahwa meskipun perusahaan memiliki pangsa pasar yang lebih besar, belum tentu melakukan pengungkapan emisi karbon yang lebih luas. Pada dasarnya perusahaan lebih berfokus pada risiko perubahan iklim dan strategi mengurangi emisi gas rumah kaca. Dengan demikian perusahaan akan diberi label bahwasannya perusahaan peduli akan keberlanjutan lingkungan. Dan akan menciptakan kesan bahwasannya perusahaan yang peduli lingkungan akan menciptakan produk yang ramah lingkungan.

\subsubsection{Pengaruh Pertumbuhan Laba terhadap Pengungkapan Emisi Karbon}

Hasil penelitian ini menujukkan bahwa $\mathrm{H}_{2}$ di tolak yang berarti pertumbuhan laba tidak memiliki pengaruh terhadap pengungkapan emisi karbon. Hal ini dapat dilihat dari nilai $\mathrm{t}$ signifikan $0.262>0.05$. Dengan demikian penelitian ini menolak $\mathrm{H}_{2}$ yang menyatakan bahwa pertumbuhan laba tidak berpengaruh terhadap pengungkapan emisi karbon.

Hasil penelitian ini mendukung penelitian Irwhantoko dan Basuki (2016) 
bahwa pertumbuhan laba tidak berpengaruh terhadap pengungkapan emisi karbon. Dikarenakan adanya perusahaan yang labanya naik tajam, namun tidak mengiringinya dengan pengungkapan emisi karbon yang lebih luas. Serta adanya perusahaan yang labanya menurun tetapi tetap mempertahankan atau memperluas pengungkapan emisi karbon. Sehingga, luas pengungkapan emisi karbon tidak bergerak seiring dengan pertumbuhan laba.

\subsubsection{Pengaruh Kinerja Lingkungan terhadap Pengungkapan Emisi Karbon}

Hasil penelitian ini menujukkan bahwa $\mathrm{H}_{3}$ diterima yang berarti kinerja lingkungan memiliki pengaruh terhadap pengungkapan emisi karbon. Hal ini dapat dilihat dari nilai $\mathrm{t}$ signifikan 0.039<0.05. Dengan demikian penelitian ini menerima $\mathrm{H}_{3}$ yang menyatakan bahwa kinerja lingkungan berpengaruh terhadap pengungkapan emisi karbon.

Hasil ini mendukung penelitian Dawkins dan Fraas (2011) bahwa kinerja lingkungan berpengaruh positif signifikan terhadap pengungkapan emisi karbon. Hasil penelitian ini konsisten dengan teori stakeholder yang menyatakan bahwa pengungkapan lingkungan dapat dijadikan sarana untuk memberitahukan aktifitas lingkungan perusahaan kepada para stakeholder. Konsisten juga dengan teori legitimasi yang menyatakan bahwa perusahaan dengan kinerja lingkungan yang baik cenderung melakukan pengungkapan lingkungan agar kepercayaan masyarakat terhadap perusahaan tetap terjaga dan masyarakat tetap memberikan dukungan penuh kepada perusahaan. Adanya pengaruh yang signifikan menjadikan hasil penelitian ini dapat digunakan sebagai dasar dalam melakukan generalisasi terkait pengaruh kinerja lingkungan yang diukur menggnakan PROPER terhadap tingkat pengungkapan emisi karbon.

\subsubsection{Pengaruh Kompetisi, Pertumbuhan Laba dan Kinerja Lingkungan terhadap Pengungkapan Emisi Karbon}

Berdasarkan hasil analisis dalam penelitian ini yang menunjukkan bahwa variabel kompetisi, pertumbuhan laba dan kinerja lingkungan tidak berpengaruh secara simultan terhadap pengungkapan emisi karbon. Hal ini ditunjukkan oleh nilai signifikansinya yaitu $0.095<0.10$. Dari hasil uji $\mathrm{F}$ ini berarti bahwa $\mathrm{H}_{4}$ ditolak. Dengan demikian kompetisi, pertumbuhan laba dan kinerja lingkungan secara simultan berpengaruh terhadap pengungkapan emisi karbon pada perusahaan manufaktur yang terdaftar di BEI tahun 2015-2018.

\section{KESIMPULAN}

Berdasarkan pengujian dan hasil penelitian yang telah dilakukan mengenai pengaruh Kompetisi, Pertumbuhan Laba dan Kinerja Lingkungan terhadap Pengungkapan Emisi Karbon, maka penulis dapat mengambil kesimpulan sebagai berikut :

1. Hasil pengujian hipotesis diperoleh bahwa variabel kompetisi tidak berpengaruh terhadap pengungkapan emisi karbon pada perusahaan manufaktur yang terdaftar di Bursa Efek Indonesia pada 2015-2018. Hal ini berarti bahwa kompetisi yang lebih besar akan memperbesar pengungkapan emisi karbon.

2. Hasil pengujian hipotesis diperoleh bahwa variabel pertumbuhan laba tidak berpengaruh terhadap pengungkapan emisi karbon pada perusahaan manufaktur yang terdaftar di Bursa Efek Indonesia pada 2015-2018. Hal ini berarti bahwa pertumbuhan laba yang lebih besar akan memperkecil pengungkapan emisi karbon.

3. Hasil pengujian hipotesis diperoleh bahwa variabel kinerja lingkungan tidak berpengaruh terhadap pengungkapan 
emisi karbon pada perusahaan manufaktur yang terdaftar di Bursa Efek Indonesia pada 2015-2018. Hal ini berarti bahwa kinerja lingkungan yang lebih besar akan memperbesar pengungkapan emisi karbon.

4. Pengujian hipotesis dengan uji $F$ dilakukan dengan melihat nilai signifikannya lebih besar dari ketetapannya yaitu $\quad 0.095<0.10$. Menunjukkan bahwa variabel kompetisi $\left(\mathrm{X}_{1}\right)$, pertumbuhan laba $\left(\mathrm{X}_{2}\right)$ dan kinerja lingkungan $\left(\mathrm{X}_{3}\right)$ berpengaruh terhadap pengungkapan emisi karbon pada perusahaan manufaktur yang terdaftar di Bursa Efek Indonesia.

\section{DAFTAR PUSTAKA.}

Ahmad, N. N. N. and D. M. Hossain. 2015. Climate Change and Global Warming Discourses and Disclosures in the Corporate Annual Reports: A Study on the Malaysian Companies. Procedia - Social and Behavioral Sciences, 172, 246-253.

Arikunto, S. 2006. Prosedur penelitian suatu pendekatan praktik. Ed Revisi VI. Penerbit PT Rineka Cipta : Jakarta.

Birt, J. L., Bilson, C. M., Smith, T., and Whaley, R. E. 2006. Ownership, competition, and financial disclosure. Australian Journal of Management, 31(2), 235-263

Choi, B., Doowon Lee and Jim Psaros. 2013. An analysis of Australian Company Carbon Emission Disclosures. Pacific Accounting Review Vol. 25 No. 1, 2013 pp. 58-79.

Ghozali, Imam. 2013. Aplikasi analisis multivariate dengan program IBM SPSS. Edisi 7. Semarang: Penerbit Universitas Diponegoro
Ghozali, Imam dan Anis Chairiri. 2007. Teori Akuntansi. Badan Penerbit Universitas Diponegoro: Semarang. Haque, Shamina dan Muhammad Azizul Islam 2012.

Irwhantoko dan Basuki. 2016. Carbon Emission Disclosure: Studi Pada Perusahaan Manufaktur Indonesia. Jurnal Akuntansi dan Keuangan, Vol. 18, No. 2, November 2016, 92-104. ISSN 1411-0288 print / ISSN 23388137 Online

Kasmir. 2012. Analisis Laporan Keuangan. Bandung: Alfa Beta.

Kelvin, Chen; Oktavianus Pasoloran \& Fransiskus Randa. 2019. Mekanisme Pengungkapan Emisi Karbon dan Reaksi Investor. Jurnal Ilmiah Akuntansi dan Bisnis (JIAB). Volume 14. Nomor 2. Juli 2019. Halaman 155168. p-ISSN 2302-514X e-ISSN 23031018.

Luo, Le, Qingliang Tang, Yi-chen Lan. 2013. Comparison of Propensity for Carbon Disclosure between Developing and Developed Countries. Accounting Research Journal Vol. 26 No. 1, 2013 pp. 6-34.

Machfoedz, Mas'ud. 1996. Akuntansi Manajemen Perencanaan dan Pembuatan Keputusan Jangka Pendek. Edisi Kelima. Buku 1. Yogyakarta: STIE-Widya Wiwaha.

Safrida, Eli. 2014. Profitabilitas dan Pertumbuhan Perusahaan Terhadap Kebijakan Deviden pada Perusahaan Manufaktur Indonesia. Politeknik Negeri Medan

Sugiyono. 2015. Metode Penelitian Pendidikan (Pendekatan Kuantitatif, Kualitatif dan R\&D). Penerbit CV. Alfabeta: Bandung 
Sugiyono. 2012. Memahami penelitian kualitatif. Penerbit CV. Alfabeta: Bandung.

Suhardi, R., dan Agus Purwanto. 2015. Analisis Faktor-Faktor yang Mempengaruhi Pengungkapan Emisi Karbon di Indonesia. Diponegoro Journal of Accounting Volume 4, Nomor 2, Tahun 2015, Halaman 1-13. http://ejournal-

s1.undip.ac.id/index.php/accounting. ISSN (Online): 2337-3806

Sukardi. 2008. Metodologi Penelitian Pendidikan Kompetensi dan Prakteknya. Jakarta: Pt Bumi Aksara

Supriadi, Agus. dkk. 2016. Data Inventory Emisi GRK Sektor Energi. Pusat Data dan Teknologi Informasi Energi dan Sumber Daya Mineral Kementerian
Energi dan Sumber Daya Mineral. ISBN:978-602-0836-22-5

Suratno, Ignatius Bondan, Darsono dan Siti Mutmainah. 2006. Pengaruh Enviromental Performance Terhadap Enviromental Disclsure dan Economic Performance. Simposium Nasional Akuntansi 9 Padang

Utama, M. 2014. Kebijakan Pasca Ratifikasi Protokol Kyoto Pengurangan Dampak Emisi Rumah Kaca dalam Mengatasi Pemanasan Global. Majalah Ilmiah Sriwijaya. 19 (11): 26-3.

United States Enviromental Protection Agency. 2014. Climate Change Indicators in the United States. EPA 430-R-14-004. 